\title{
Kualitas Air Minum Yang Diproduksi Depot Air Minum Isi Ulang Di Kecamatan Bungus Padang Berdasarkan Persyaratan Mikrobiologi
}

\author{
Rido Wandrivel, Netty Suharti, Yuniar Lestari
}

\begin{abstract}
Abstrak
Latar belakang: Pendahuluan: Setiap depot air minum wajib melakukan pemeriksaan mutu produk sesuai dengan peraturan yang berlaku, namun tidak satupun dari sembilan depot air minum di Kecamatan Bungus melakukan hal tersebut. Diare adalah salah satu penyakit yang disebabkan oleh air minum yang tidak berkualitas. Morbiditas rate diare di Kecamatan Bungus tertinggi ke-2 di Kota Padang. Penelitian ini bertujuan untuk mengetahui kualitas air minum yang dihasilkan depot air minum di Kecamatan Bungus berdasarkan persyaratan mikrobiologi. Metode Penelitian: Populasi pada penelitian ini adalah air minum yang berasal dari depot air minum isi ulang di Kecamatan Bungus Padang dan sampel pada penelitian ini adalah seluruh populasi yang ada, yaitu sembilan sampel. Penelitian dilaksanakan dalam 2 tahap yaitu pengambilan sampel air dengan galon air sekaligus observasi faktor yang mempengaruhi kualitas air dan pemeriksaan mikrobiologis dengan Most Probable Number Test (MPN) terhadap sampel yang terdiri dari tiga tes, yaitu presumptive test, confirmative test, dan complete test. Hasil Penelitian: Lima dari sembilan sampel mengandung bakteri Coliform dan tiga dari lima sampel tersebut juga mengandung $E$. coli. Kesimpulan: Hal ini menunjukkan bahwa 55,6\% depot air minum di Kecamatan Bungus menghasilkan air minum yang kualitasnya tidak memenuhi persyaratan mikrobiologi yang telah ditetapkan pemerintah. Beberapa faktor yang dapat mempengaruhi adalah air baku, kondisi depot, kebersihan operator, dan penanganan terhadap wadah pembeli.
\end{abstract}

Kata kunci: Depot air minum isi ulang, pemeriksaan mikrobiologis

\begin{abstract}
Background: Every depot is obliged to do inspection of product quality prescribed by the regulations, but not one even also from nine drinking water depot in District of Bungus do the mentioned. Diarrhea is one of the disease that cause by bad quality water product. Diarrhea morbidity rate in the Bungus District is second highest in Padang City. This Research aim to to know the drinking water quality produced by drinking water refill depot in the Bungus District based on microbiological requirements. Methods: Population of this research is drinking water refill depots in the Bungus District of Padang city and sample of this research is all of existing population, that is nine drinking water depot. Research executed in 2 phase that is intake of water sample with gallon at the same time do observation of the factor that influencing the quality of water and mikrobiological test with Most Probable Number Test ( MPN) to the sampel which consist of three test, that is presumtive test, konfirmative test, and complete test. Result: Five from nine sample contain coliform bacteria and three from five the sampel also contain E. coli. Conclusion: This matter indicate that $55,6 \%$ drinking water refill depot in District of Bungus produce drinking water which its quality don't fulfill microbiological requirements which have been specified by government. Some factor able to influence is standard water, condition of depot, hygiene of operator, and handling to place of buyer.
\end{abstract}

Keywords: Drinking water refill depots, mikrobiological test

Affiliasi penulis : Fakultas Kedokteran Universitas Andalas (mahasiswa)

Korespondensi : Rido wandrivel rido_1drivel@yahoo.com Telp: 085274105765

\section{Pendahuluan}

Air merupakan zat yang paling penting dalam kehidupan setelah udara. Tiga per empat bagian tubuh manusia terdiri dari air. Manusia tidak dapat bertahan hidup lebih dari 4-5 hari tanpa minum air. Air juga merupakan zat yang paling parah akibat pencemaran. Penyakit-penyakit yang menyerang manusia dapat ditularkan dan disebarkan melalui air. Penyakitpenyakit tersebut merupakan akibat semakin tingginya kadar pencemar yang memasuki air. ${ }^{3,20}$

Pengadaan air bersih untuk keperluan air minum, harus memenuhi persyaratan yang sudah ditetapkan oleh pemerintah. Air minum aman bagi kesehatan apabila memenuhi persyaratan secara fisika, mikrobiologi, kimia, dan radioaktif. Parameter wajib penentuan kualitas air minum secara mikrobiologi adalah total bakteri Coliform dan Escherichia coli. ${ }^{5}$ Penentuan kualitas air secara mikrobiologi dilakukan dengan Most Probable Number Test. Jika di dalam $100 \mathrm{ml}$ sampel air didapatkan sel bakteri Coliform memungkinkan terjadinya diare dan gangguan pencernaan lain. ${ }^{20}$

Sekitar tahun 1999, mulai muncul usaha depot air minum isi ulang (18). Depot air minum adalah usaha industri yang melakukan proses pengolahan air baku menjadi air minum dan menjual langsung kepada pembeli. Pengujian mutu produk wajib dilakukan oleh depot air minum di Laboratorium Pemeriksaan Kualitas Air yang ditunjuk oleh Pemerintah Kabupaten/Kota atau yang terakreditasi sekurang-kurangnya 6 (enam) bulan sekali. Pengujian tersebut bertujuan menjamin mutu produk air minum 
yang dihasilkan, mendukung terciptanya persaingan usaha yang sehat, dan sebagai upaya perlindungan kepada konsumen. $(8,12)$

Depot air minum merupakan jenis sumber air minum terbanyak ketiga yang digunakan masyarakat Sumatera Barat berdasarkan Riset Kesehatan Dasar (Riskesdas) 2010 dengan persentase 17,2 \% setelah sumur gali terlindung dan air ledeng dengan persentase masing-masing $22,1 \%$ dan 20,8 \% (4). Jumlah depot air minum isi ulang di Kota Padang berdasarkan data dari Dinas Kesehatan Kota Padang per November 2011 sebanyak 604 depot. Depot air minum isi ulang yang melakukan pemeriksaan mutu produk air dari Juni sampai November 2011 atau yang memenuhi Keputusan Menteri Perindustrian dan Perdagangan (Kepmenperindag) No. 651 Tahun 2004 sebanyak 120 depot. Kecamatan Bungus merupakan satu-satunya kecamatan di Kota Padang dengan depot air minum yang tidak melakukan uji produk air sesuai dengan aturan yang berlaku. Tidak satupun dari sembilan depot air minum yang melakukan pengujian produk air. (9)

Salah satu penyakit yang disebabkan oleh air minum yang kualitas mikrobiologisnya buruk adalah diare (20). Diare termasuk sepuluh penyakit terbanyak di Kota Padang. Berdasarkan profil kesehatan Kota Padang tahun 2010, jumlah kasus diare sebanyak 12.744 kasus. Morbidity rate diare di Kecamatan Bungus yaitu 21,3 dan merupakan morbidity rate diare tertinggi ke dua di Kota Padang setelah Kecamatan Padang Selatan yaitu 29. (5)

Penelitian ini dilakukan dengan tujuan untuk Mengetahui kualitas air minum yang di produksi depot air minum isi ulang di Kecamatan Bungus Padang berdasarkan persyaratan mikrobiologis yang ditetapkan oleh Peraturan Menteri Kesehatan No. 492 Tahun 2010 tentang persyaratan kualitas air minum.

\section{Metode}

Penelitian ini dilakukan di Laboratorium Mikrobiologi Fakultas Kedokteran Universitas Andalas Padang bulan November 2011 sampai Mei 2012. Sampel pada penelitian ini adalah air minum dari seluruh depot air minum isi ulang di Kecamatan Bungus Padang sebanyak sembilan depot. Penelitian ini adalah penelitian deskriptif laboratorium. Penelitian dilakukan dengan terlebih dahulu mengobservasi beberapa faktor yang mungkin mempengaruhi kualitas air minum yang dihasilkan depot, kemudian melakukan pemerikaan mikrobiologi dengan menggunakan Most Probable Number Test yang terdiri dari presumptive test menggunakan medium lactose broth, confirmative test menggunakan medium Brilliant green lactose broth, dan complete test menggunakan medium endo agar.

\section{Hasil dan Pembahasan}

Tabel 1. Faktor yang mempengaruhi kualitas air minum berdasarkan hasil observasi.

\begin{tabular}{lll}
\hline No. & Faktor yang mempengaruhi & $\%$ \\
\hline 1. & Sumber air baku & \\
& a. Gunung Talang, Solok & $55,6 \%$ \\
& b. Perbukitan sekitar Bungus & $33,3 \%$ \\
& C. PDAM & $11,1 \%$ \\
2. Kondisi depot & \\
\hline & a. Lokasi \\
\hline
\end{tabular}

\begin{tabular}{lll}
\hline 1. & Tersendiri & $55,6 \%$ \\
2. $\quad$ Bergabung dengan aktivitas & $44,4 \%$ \\
& lain & \\
b. Perawatan & $77,8 \%$ \\
1. Terawat & $11,1 \%$ \\
2. Tidak terawatt & $11,1 \%$ \\
3. Tidak diketahui & \\
c. Tempat pengisian air minum & $88,9 \%$ \\
& Tertutup kaca & $11,1 \%$ \\
Terbuka & $0 \%$ \\
3. Operator depot mencuci tangan & \\
4. Penanganan terhadap wadah & \\
pembeli & $44,4 \%$ \\
a. Penyikatan dan Pembilasan & $44,4 \%$ \\
b. Pembilasan & $11,2 \%$ \\
\hline c. Tidak ada
\end{tabular}

Tabel 1 menunjukkan beberapa faktor yang dapat mempengaruhi kualitas air minum isi ulang yang dihasilkan, yaitu: sumber air baku, kondisi depot, kebersihan operator, dan penanganan terhadap wadah pembeli sebelum diisi dengan air minum.

Tabel 2. Hasil tes presumtif

\begin{tabular}{ccccc}
\hline $\begin{array}{c}\text { No } \\
\text { sampel }\end{array}$ & \multicolumn{3}{c}{ Tes Presumtif } & Ket. \\
& $10 \mathrm{cc}$ & $1 \mathrm{cc}$ & $0,1 \mathrm{cc}$ & \\
\hline 1 & +++ & + & - & lanjut \\
2 & - & - & - & Negatif \\
3 & - & - & - & Negatif \\
4 & ++ & ++ & - & lanjut \\
5 & ++ & - & - & lanjut \\
6 & +++ & +++ & +++ & lanjut \\
7 & + & - & - & lanjut \\
8 & - & - & - & Negatif \\
9 & - & - & - & Negatif
\end{tabular}

${ }^{*}+=$ terdapat produksi gas

Berdasarkan tabel 2 didapatkan bahwa jumlah tabung yang positif pada tes presumtif sebanyak 20 tabung $(24,7 \%)$ dari total tabung reaksi yang digunakan. Dari hasil tersebut didapatkan bahwa lima dari sembilan sampel $(55,5 \%)$ sampel air, sampel $1,4,5,6,7$, menunjukkan hasil positif pada tes presumtif. Sampel yang positif dilanjutkan ke tes konfirmatif.

Tabel 3. Hasil tes konfirmatif

\begin{tabular}{|c|c|c|c|c|c|c|c|c|c|}
\hline Sampel+ & \multicolumn{3}{|c|}{ Vol 10cc } & \multicolumn{3}{|c|}{ Vol 1cc } & \multicolumn{3}{|c|}{ Vol 0,1cc } \\
\hline 1 & + & + & + & + & - & - & - & - & - \\
\hline 4 & + & + & - & + & + & - & - & - & - \\
\hline
\end{tabular}




\begin{tabular}{lllllllllll}
\hline 5 & + & + & - & - & - & - & - & - & - \\
6 & + & + & + & + & + & + & + & + & + \\
7 & + & - & - & - & - & - & - & - & - \\
\hline
\end{tabular}

Tabel 3 menunjukkan bahwa semua hasil positif pada tes presumtif juga menunjukkan hasil positif pada tes konfirmatif. Produksi gas pada tabung reaksi tersebut menunjukkan adanya pertumbuhan koloni bakteri Coliform pada medium yang digunakan, sehingga hasil positif pada tes konfirmatif dapat dimasukkan kedalam tabel jumlah perkiraan terdekat untuk mendapatkan total bakteri Coliform yang terkandung dalam $100 \mathrm{ml}$ sampel air seperti yang terlihat pada tabel 4 di bawah ini:

Tabel 4. bakteri Coliform dalam $100 \mathrm{ml}$ sampel air berdasarkan tabel JPT

\begin{tabular}{|c|c|c|c|c|}
\hline \multirow[t]{2}{*}{ Sampel } & \multicolumn{3}{|c|}{ Jumlah hasil positif } & \multirow{2}{*}{$\begin{array}{c}\text { Total } \\
\text { bakteri } \\
\text { Coliform }\end{array}$} \\
\hline & $\begin{array}{l}3 \text { dari } \\
10 \mathrm{ml}\end{array}$ & $\begin{array}{c}3 \text { dari } \\
1 \mathrm{ml}\end{array}$ & $\begin{array}{l}3 \text { dari } \\
0,1 \mathrm{ml}\end{array}$ & \\
\hline 1 & 3 & 1 & 0 & 43 \\
\hline 4 & 2 & 2 & 0 & 21 \\
\hline 5 & 2 & 0 & 0 & 9 \\
\hline 6 & 3 & 3 & 3 & 2400 \\
\hline 7 & 1 & 0 & 0 & 4 \\
\hline
\end{tabular}

Tabel 5. Hasil tes lengkap

\begin{tabular}{cccc}
\hline No. & Sampel & Koloni E. coli & Hasil \\
\hline 2. & 1 & Ditemukan & Positif \\
2. & 4 & $\begin{array}{c}\text { Tidak } \\
\text { ditemukan }\end{array}$ & Negatif \\
3. & 5 & Ditemukan & Positif \\
4. & 6 & $\begin{array}{c}\text { Ditemukan } \\
\text { Tidak }\end{array}$ & Positif \\
5. & 7 & Negatif
\end{tabular}

Tabel 5 menunjukkan tiga dari lima sampel atau $60 \%$ sampel yang mengandung bakteri Coliform, yaitu sampel 1,5, dan 6 mengandung $E$. coli, sedangkan dua sampel lainnya menunjukkan pertumbuhan koloni bakteri lain. Pada reaksi biokimia ditemukan kuman Pseudomonas sp.

Dari hasil penelitian ini didapatkan lima dari sembilan sampel atau $55,6 \%$ sampel tidak memenuhi persyaratan yang telah ditetapkan berdasarkan Peraturan Menteri Kesehatan No. 492 Tahun 2010. Dari lima sampel penelitian yang positif, tiga sampel mengandung $E$. coli, sementara dua sampel lain mengandung bakteri Coliform lain. Bakteri Coliform/E. Coli terdapat pada lingkungan alami dan pada feses manusia dan binatang. Kelompok bakteri ini umumnya tidak membahayakan kesehatan, tapi kehadiran bakteri Coliform/E. Coli dalam badan air mengindikasikan air tersebut sudah tercemar. Hal ini juga mengindikasikan buruknya kualitas mutu produk air minum isi ulang yang dihasilkan depot air minum. Temuan ini berbeda dengan hasil penelitian tentang kualitas air minum isi ulang sebelumnya. Hasil analisis laboratorium Institut Pertanian Bogor tahun 2002, dari 120 sampel Air Minum isi ulang dari 10 kota besar di Indonesia (Jakarta, Bogor, Tangerang, Bekasi, Cikampek, Semarang, Yogyakarta, Surabaya, Medan, dan Denpasar) ditemukan sekitar 16\% sampel terkontaminasi bakteri Coliform.(19) Penelitian yang dilakukan Supriyono Asfawi tahun 2004, dari 49 sampel depot air minum isi ulang di kota Semarang, sebanyak 15 depot $(30,6 \%)$ tidak memenuhi syarat sebagai air minum. Perbedaan ini mungkin terjadi karena sumber air baku yang digunakan depot pada penelitian sebelumnya mempunyai kualitas lebih baik, peralatan yang digunakan baik dan terawat, dan penangan terhadap wadah pembeli serta kebersihan operator depot lebih diperhatikan.

Beberapa faktor yang dapat mempengaruhi kualitas produk air yang dihasilkan adalah bahan baku, penanganan terhadap wadah pembeli, kebersihan operator, dan kondisi depot. 55,6\% depot air minum menggunakan bahan baku yang berasal dari Gunung Talang, Solok, namun hasil yang didapatkan pada pemeriksaan mikrobiologi menunjukkan adanya perbedaan, dimana $80 \%$-nya menunjukkan hasil negatif terhadap total bakteri Coliform yang berarti mempunyai produk air yang berkualitas, sementara 20\%-nya menunjukkan hasil positif mengandung bakteri Coliform dan E. coli. Hasil positif yang didapatkan ini menunjukkan bahwa efektifitas proses pengolahan bahan baku menjadi produk air minum mungkin juga mempengaruhi kualitas air yang dihasilkan. Proses yang dimaksud disini meliputi penampungan/penyimpanan bahan baku, penyaringan, desinfeksi, dan sanitasi tempat pengolahan air minum atau sistem distribusi pada pipa penyalur air minum, serta kondisi peralatan yang digunakan pada proses tersebut. $(8,18)$

Kualitas bahan baku tentu sangat menentukan kualitas produk air minum yang dihasilkan. Produk air dari depot air minum dengan bahan baku yang berasal dari perbukitan di sekitar bungus memberikan hasil positif mengandung bakteri Coliform. Oleh karena itu perlu dikaji lagi apakah bahan baku yang berasal dari daerah tersebut layak digunakan sebagai bahan baku untuk diolah menjadi air minum. Bahan baku utama yang seharusnya digunakan adalah air yang diambil dari sumber yang terjamin kualitasnya, yaitu terlindungi dari cemaran kimia dan mikrobiologi yang bersifat merusak/mengganggu kesehatan, serta diperiksa secara berkala terhadap organoleptik (bau, rasa, warna), fisika, kimia, dan mikrobiologi.(8) Sampel yang bahan bakunya berasal dari air PDAM menunjukkan hasil positif mengandung bakteri Coliform. Maka perlu juga dikaji lagi apakah air PDAM layak dijadikan sebagai bahan baku untuk depot air minum yang umumnya mengambil bahan baku dari mata air pegunungan.

Penanganan terhadap wadah yang dibawa pembeli juga mempengaruhi kualitas air di dalamnya. Walaupun air yang dihasilkan berkualitas, tapi jika tidak ada perhatian lebih terhadap wadah galon sebagai tempat untuk mengisikan maka akan 
memungkinkan terjadi kontaminasi terhadap air yang dihasilkan (Depkes, 2003). Pencucian harus dilakukan dengan menggunakan berbagai jenis deterjen tara pangan (food grade) dan air bersih dengan suhu berkisar $60-85^{\circ} \mathrm{C}$, kemudian dibilas dengan air minum/air produk secukupnya untuk menghilangkan sisa-sisa deterjen yang dipergunakan untuk mencuci.(8) Semua depot air minum yang terdapat di Kawasan Bungus Padang tidak melakukan penanganan terhadap wadah yang dibawa pembeli sesuai dengan peraturan tersebut. Cara yang umum dilakukan oleh depot air minum dalam menangani wadah pembeli adalah dengan menyikat dan membilas dengan produk air, setelah itu langsung diisi. Pada $44,4 \%$ depot air yang menggunakan cara ini, menyikat dan membilas, didapatkan hasil kualitas air yang bagus dan tidak mengandung bakteri Coliform. Sementara depot yang hanya membilas tanpa menyikat ditemukan mengandung bakteri Coliform. Depot yang tidak menyikat dan membilas wadah pembeli didapatkan mempunyai kandungan total Colifom tertinggi dibanding sampel positif lainnya.

Faktor lain yang mempengaruhi kualitas air yang dihasilkan suatu depot air minum adalah kondisi depot air minum tersebut. Lokasi di depot air minum harus terbebas dari pencemaran yang berasal dari debu disekitar depot dan tempat-tempat lain yang diduga dapat mengakibatkan pencemaran.(8) Depot yang tidak berdiri sendiri dan bergabung dengan tempat aktivitas lain sebanyak $44,4 \%$, hal ini memungkinkan terjadinya pencemaran dari lingkungan sekitar. Kebersihan depot harus selalu terjaga untuk menghindarkan kontaminasi. Empat dari sembilan depot berdiri sendiri dan terlihat terawat dan tiga dari 4 depot tersebut atau 75\%-nya tidak mengandung bakteri koliform atau memberikan kualitas air yang sesuai aturan. Depot yang sudah tersendiri tapi tidak terawat memberikan hasil positif mengandung bakteri Coliform dan E. coli.

Pengetahuan operator depot air minum tentang kebersihan tentu juga akan mempengaruhi kualitas air yang dihasilkan. Hanya sebagian kecil penjual sekaligus operator pada depot air minum yang mengerti betul arti kebersihan baik pada tempat proses air, lingkungan sekitar, pakaian yang dikenakan, dan kebersihan diri sendiri.(18) Mencuci tangan adalah salah satu bentuk menjaga kebersihan diri sendiri, namun tidak satupun dari sembilan operator air minum pada depot air minum isi ulang di Kawasan Bungus Padang yang mencuci tangan sebelum melayani pembeli.

Berdasarkan data yang didapatkan pada penelitian ini, 55,6\% depot air minum di Kecamatan Bungus menghasilkasn produk air minum yang tidak memenuhi standar air minum secara mikrobiologi yang aman bagi kesehatan. Data dari Dinas Kesehatan Kota Padang tentang depot air minum di Kota Padang per November 2011 menunjukkan bahwa 484 dari 604 atau $80,13 \%$ depot air minum di Kota Padang tidak melakukan pengujian mutu produk air sesuai peraturan yang berlaku. Jumlah ini tentu sangat memprihatinkan mengingat 5 dari sembilan depot air minum di Kecamatan Bungus tidak memenuhi standar air minum yang aman bagi kesehatan. Pengujian mutu produk yang tidak dilakukan tidak dapat menjamin air yang dihasilkan bebas dari pencemaran dan aman bagi kesehatan masyarakat. Peran pemerintah dan pihak terkait yang dalam hal ini adalah Dinas Kesehatan tentu sangatlah penting. Pengawasan terhadap penyelenggaraan usaha depot air minum perlu ditingkatkan mengingat banyaknya depot yang tidak memeriksakan mutu produk air masih beroperasi dan melayani konsumen. Pihak yang berwenang sudah seharusnya menindak tegas depot air minum isi ulang yang tidak memenuhi persyaratan yang sudah ditetapkan..

Kesimpulan

Berdasarkan penelitian ini dapat disimpulkan bahwa Kualitas air minum yang diproduksi depot air minum isi ulang di Kecamatan Bungus Padang berdasarkan hasil pemeriksaan laboratorium menunujukkan 55,5\% sampel tidak memenuhi persyaratan secara mikrobiologi yang ditetapkan berdasarkan Peraturan Menteri Kesehatan No. 492 Tahun 2010. Hasil pemeriksan laboratorium mikrobiologi menunjukkan bahwa lima dari sembilan sampel mengandung bakteri Coliform. Tiga dari lima sampel yang mengandung bakteri Coliform ternyata bakterinya adalah Escherichia coli.

\section{Daftar Pustaka}

1. Asfawi, S, 2004. Analisis Faktor yang Berhubungan dengan Kualitas Bakteriologis Air Minum Isi Ulang pada Tingkat Produsen di Kota Semarang Tahun 2004. Tesis, Universitas Diponegoro, Semarang.

2. Boyd RF, BG Hoerl, 1980. Medical Microbiology, $1^{\text {st }}$ edition. Boston : Little Brown and Company.

3. Chadra, B, 2005. Pengantar Kesehatan Lingkungan. Jakarta : Penerbit Buku Kedokteran.

4. Departemen Kesehatan RI, 2011, Profil Kesehatan Indonesia 2010. Jakarta : Kementrian Kesehatan Republik Indonesia.

5. Departemen Kesehatan RI, 2010. Peraturan Menteri Kesehatan No. 492 Tahun 2010 tentang Persyaratan Kualitas Air Minum.

6. Departemen Kesehatan RI, 2006. Pedoman Pelaksanaan Penyelenggaraan Hygene Sanitasi Depot Air Minum., Dirjen Penyehatan Lingkungan, Jakarta.

7. Departemen Kesehatan RI, 2003. Pedoman dan Pengawasan Higiene Sanitasi Depot Air Minum, Direktorat Penyehatan Air dan Sanitasi WHO dan Depkes RI, Jakarta.

8. Departemen Perindustrian dan Perdagangan RI, 2004. Keputusan Menteri Perindusrtian dan Perdagangan No. 651 Tahun 2004 tentang Persyaratan Teknis Depot Air Minum dan Perdagangannya.

9. Dinas Kesehatan Kota Padang, 2011. Depot Air Minum Isi Ulang di Kota Padang per November 2011.

10. Edzwald JK, 2011. Water Quality and Treadment : a Handbook on Drinking Water. New York : Mc Graw Hill, 21.13.

11. Kementerian Kesehatan RI, 2011. Profil Kesehatan Indonesia $2010 . \quad$ Jakarta Kementerian Kesehatan RI.

12. Kusnaedi, 2006. Pengolahan Air Gambut dan Air Kotor untuk Air Minum. Jakarta: Penebar Swadaya.

13. Latterman, Raymond D. 1999, Water Quality and Treatment : a Handbook of Community Water Supply, $5^{\text {th }}$ ed. New York : Mc Graw Hill.

14. Maiti, S.K, 2004, Handbook of Methods in Environmental Studies. Vol 1 : Water \& Wastewater Analysis. Jaipur : ABD Publishers. 
15. Migliaccio K, Yuncong Li, 2011. Water Quality Concepts, Sampling, and Analyses. USA : CRC Press.

16. Morello, Josephine A, Paul A. Granato, Helen Eckel Mizer, 2003. Laboratory and Workbook in Microbiology : Aplications to Patient Care, $7^{\text {th }} \mathrm{ed}$, New York : Mc Graw Hill.

17. Okafor, N, 2011, Environmental Microbiology of Aquatic and Waste System. New York : Springer Science \& Business Media.

18. Pitoyo, 2005. Dua Jam Anda Tahu Cara Memastikan Air yang Anda Minum Bukan Sumber Penyakit, Solo.
19. Suprihatin, 2003. Hasil Studi Kualitas Air Minum Depot Isi Ulang. Makalah pada Seminar Sehari Permasalahan Depot Air Minum dan Upaya Pemecahannya.

20. Suriawiria, U, 2008. Mikrobiologi Air dan Dasardasar Pengolahan Buangan Secara Biologis. Bandung :Penerbit Alumni.

21. WHO, 2011, Guidelines for Drinking-Water Quality. Malta : WHO press.

22. Willey, Joanne $M$, Linda $M$. Sherwood, Christopher J, 2008. Prescott, Harley, and Klein's Microbiology. New York : Mc Graw Hill. Pp 272274.

23. Zuane, J, 1997, Handbook of Drinking Water Quality, $2^{\text {nd }}$ Ed. New York : John Wiley \& Sons, INC. 